\title{
The Application of German Vocational Education Example Teaching Method*
}

\author{
Wang Xiaoqing \\ Yunnan Open University, kunming, China
}

\begin{abstract}
As college education courses in the implementation of the practice teaching, also want to reflect education courses of ideological and political education purpose, and in view of higher vocational education, higher vocational students' characteristics and laws. Sample in this paper, using the German vocational education teaching in higher vocational colleges education courses of the use of practice teaching, practice teaching research in higher vocational education courses teaching, strengthening the ideological and political theory course in higher vocational colleges education teaching pertinence, effectiveness and persuasive and appealing.

Index Terms - Example teaching method. Higher vocational education courses teaching practice. Teaching law
\end{abstract}

Example teaching method is a relatively regarded German vocational ability development, also study more deeply a kind of teaching method. Example teaching method according to the characteristics of vocational education and laws, in the face of students to learn knowledge but not after application, especially not moved the learned knowledge and the reality of different situation, advocated by example teaching form to realize students' mastery of curriculum knowledge, and at the same time of mastering, into professional ability.

In the example teaching method, the example to solve the problem is a special example of it and solve the problem by the method of detailed description, can be called a special instructions. If in actual education teaching, learners can choose between the abstract study data and examples, practice shows that most of these students will tend to sample. German vocational education experts study shows that not only learners for example good reflection is a good prove that this method is feasible, and many researchers are in favor of the efficiency of higher learning method. When learners on the analysis of the example shown enthusiasm is the key. Learning is effective is the key to learners can you get the steps to solve the problem solution process.

\section{1. "Thought Morals Tutelage and Legal Foundation" Course Practice Teaching Process}

Based on the research of German vocational education experts for example teaching method, the author through the "thought morals tutelage and legal foundation" course teaching practice, according to the characteristics and rules of higher vocational teaching, students' application example teaching method, strengthen students in the practice teaching link partial understanding of the ideological and political theory course, and translated into the students' ability to act. Below to biological technology and application of professional practice of "thought morals tutelage and legal foundation" class, for example, look at examples of German vocational education teaching in education courses, the application of the practice.

\subsection{Courses to Prepare.}

"Thought morals tutelage and legal foundation" is mainly for moral education and legal education, help students to enhance legal concept, improve the ideological and moral qualities, to solve the practical problems encountered in the process of growing up. In the practice teaching link, the key lies in the "thought morals tutelage and legal foundation" teaching material in theory to improve students' ideological and political quality and the ability to analyze the social phenomena, deepening the education teaching effect. Based on the teaching requirements and teaching purposes, in the course design, taken from problems, combined with the characteristics of students, namely the classes belongs to biological technology and application of professional courses, improve the students' ideological and moral quality, combining the theory of curriculum teaching of "moral" part of the study and biological technology and application needs. For students professional and career development guidance, combined with "thought morals tutelage and legal foundation" teaching requirements, practical teaching theme as "biological technology and application of industry practitioners should possess professional morality accomplishment". On practice teaching topic, the teaching of writing curriculum requirements.

\subsection{Course content.}

According to the practice teaching subject "biological technology and application of industry practitioners should possess professional morality accomplishment", course requirements mainly from the organization report preparation, practice, practice report PPT three aspects, such as the specific requirements are put forward. One is the organization preparation. To do a good job of the establishment of the organization, from the organizational guarantee for the prophase preparation in practice teaching. Secondly, the practice report. In order to reach the requirement of example teaching method, unified the practice report writing made

\footnotetext{
* Author's brief introduction: Wang Xiaoqing, Associate professor, Yunnan Open University ,kunming, China Contact phone number: 13888293915,E-mail: wxq8978@tom.com

Contact address: YunNan Kunming city xuefu road no. 113 Yunnan Open University
} 
specific demands, from practice report length words to practice writing content to do the detailed requirements, to ensure realization of "thought morals tutelage and legal foundation" teaching. 3 it is to practice report PPT production requirements. Practice report into PPT form, mainly in order to enrich the expression means and forms of teaching, through
PPT making represent "biological technology and application of industry practitioners should possess professional morality accomplishment", the content of the image is more vivid and improve the students' learning interest, promote students will practice the paper form into the visual effect of image theory, promote the education courses teaching effect.

\begin{tabular}{|c|c|c|}
\hline \multirow{3}{*}{$\begin{array}{l}\text { Practice teaching } \\
\text { course content }\end{array}$} & Set of woven & $\begin{array}{l}\text { 1. A practice team, each group of four people. } \\
\text { 2. After the collection of data in each group to complete a group PPT homework, a practice } \\
\text { report. } \\
\text { 3. Each group recommend a team representative to speak to a member, this practice class } \\
\text { assignments. } \\
\text { 4. Practice class assessment by each group recommend a representative to complete the } \\
\text { inspection. }\end{array}$ \\
\hline & The practice report & $\begin{array}{l}\text { 1. Practice report requires more than } 2000 \text { words; } \\
\text { 2. The practice report must include the following contents: } \\
\text { 1)The concept and characteristics of moral; } \\
\text { 2)The content and requirements of professional ethics; } \\
\text { 3)Biological technology and application of professional content; } \\
\text { 4)Biological technology and application of professional ethics; } \\
\text { 5)As a biological technology and application of the employees, how to follow the professional } \\
\text { ethics of biological technology and application of industry. }\end{array}$ \\
\hline & $\begin{array}{l}\text { Requirements of } \\
\text { making the PPT }\end{array}$ & $\begin{array}{l}\text { 1. PPT production report content should combine practice; } \\
\text { 2. PPT content must be innovative and creative; } \\
\text { 3. PPT requirements slides } 20 \text { picture above; } \\
\text { 4. PPT production support services to implement the practice class content. }\end{array}$ \\
\hline
\end{tabular}

2-1 Practice teaching course content

\subsection{Course step.}

Curriculum implementation is mainly divided into three stages. The first phase is the data collection, writing papers, making PPT. This stage is mainly students use spare time to get the job done. Show the second stage is homework, mainly group means the defendant through PPT report team complete situation and this paper team practice teaching theme "biological technology and application of industry practitioners should possess professional morality accomplishment" writing thesis. Course review the third stage is to guide teachers, mainly is the classroom teachers in the process of practice teaching link to follow their Suggestions to the opinions of the practice teaching link, help students to enhance awareness in the process of practice teaching, to maximize the teaching effect.

\subsection{Course evaluation and feedback of teaching.}

Curriculum evaluation to students' self-assessment and guide teacher evaluation of two parts. The first part is students' self-assessment main operation by the students themselves. Students in accordance with the requirements of practice teaching link teaching design evaluation form, evaluation content includes the "team coordination ability, speaker's language expression ability, team consciousness of classroom discipline, PPT production, interpretation of the supplement (result), paper assignments, the practice class overall rating scores", etc. The second part is to guide teachers evaluation, mainly in the students' self evaluation to guide the evaluation essay assignments. Two parts after the evaluation work, members of the working party last measure each group by the students in the link of practice teaching.

After implementing the practice teaching student cadre is responsible for organizing the practice teaching effect in the questionnaire. With the help of the teacher, is responsible for the effect of student cadre, 10 questionnaire problem is mainly around the arrangement of the practical teaching plan, practice teaching process, students' practical learning content of information feedback. By the student cadre to student to carry on the questionnaire survey and statistics. The questionnaire recovery rate $100 \% .81 \%$ of the students "practice done to practice lessons before class related information collection".80\% of the students "practice and students have done before class and practice class related discussion". To practice class participation, $72 \%$ of the students are actively involved in, $20 \%$ of the students is "general participation". The class associated with professional degree "practical",41\% of the students thought that "close contact", 59\% of the students thought that "associations".63\% of the students thought that practice class effect is "very good", $36 \%$ of the students thought that "general", $2 \%$ of the students thought that "boring". In "practice lesson in this form to the thought politics theory class teaching effect" of knowledge, $70 \%$ of the students thought that "very good", $27 \%$ of the students thought that "good", 3\% of the students thought that "general".

The characteristic of the questionnaire and mainly: the classmates, thought are consistent, obvious effect, a goal. 


\section{Example Teaching Method of Practice Teaching of Ideological and Political Theory}

\subsection{The influence of autonomous solutions enthusiasm}

Around "biological technology and application of industry practitioners should possess professional morality accomplishment" theme in the process of study practice class, task arrangement, to students in independent study to collect data, write a thesis topic, making PPT report process, put forward specific demands. Students in learning practice independently analyze teachers give information about practice class theme, with his mastery of knowledge, positive analysis and try, to accomplish specific learning work according to the requirements. Completed in learning results show a good team, can be a very good according to course requirements, have a purpose to complete the learning process, especially some team to achieve the "thought morals tutelage and legal foundation" fusion of moral education and professional development requirements, such as essay writing, teachers require paper content must have a "moral the concept and characteristics of the content and requirements of professional ethics; biological technology and application of professional content; biological technology and application of professional ethics, as a biological technology and application of the employees, how to follow the biological technology and application of industry professional ethics?" Six parts, such as But the actual completed, has a group of autonomous expanded the content, increase the "introduction to biological technology and application of professional curriculum setting; biological technology development trend and application of professionals in industry", embodies the "independent answer effect" of learning. By doing good team work, for some learning passively, enthusiasm is not high classmates, had a promoting effect. Example teaching method in practice teaching, students' autonomous explain motivation and "shallow lines" and "deep lines" completion of the practice teaching goal has played a positive effect.

\subsection{The influence of the diversity of the sample}

In the practice teaching, guiding the teacher in order to guarantee according to the practice teaching tasks to complete teaching plan, implementation of "thought morals tutelage and legal foundation" course teaching purpose, the original completed in advance of other professional class to show students the practice teaching of homework, equivalent to other professional examples are given, such examples from different professional class with curriculum of diversification. Through compare to other professional practice teaching example, students can distinguish good example and a bad example, also realized to learn "thought morals tutelage and legal foundation" course theory knowledge transformation and utilization.

In the process of operation show, because it is 11 team to display, so that different groups from the same class realized the diversity of the sample. Due to the start of the practice teaching content of paper made rules, making 11 examples team made the work roughly the same case, shows each group of practice teaching theme "biological technology and application of industry practitioners should possess professional morality accomplishment" of different understanding and explanation. Some groups to show "biological technology and application of industry practitioners should possess professional morality accomplishment", when the PPT show, "food safety" from the current social problems, this "biological technology and application of industry practitioners should possess professional morality accomplishment" should be included in the "social responsibility" of professional ethics.

\subsection{The influence of teachers' guidance}

In teaching, practice teaching teachers to guide the effective finish plays an important role. First of all, in the "biological technology and application of industry practitioners should possess professional morality accomplishment" theme practice teaching process, teachers in the early stage of the learning task must be in the arrangement of teaching requirements detailed clear to all students, and be sure to tell students, the practice teaching to achieve the purpose of the study data collection, thesis writing, such as PPT production steps one by one, under the principle provision, lets the student have extended space. Second, when learning to show must respect the students' learning initiative. Study shows due to major presided over by the students themselves to complete, this stage teachers are mainly involved in, main job is to promote learning effect to the development of curriculum requirements. Finally, review the course of teachers for the completion of teaching tasks will have the effect of ascension. This stage is mainly to review the whole process of teaching practice shows, teachers practice teaching must be closely around the theme, for according to the plan to complete the team has a characteristic, the extended team to review key in the process of complete effect to analysis the causes of lack of group, points out problems, solutions and measures are put forward.

\subsection{The influence of background knowledge.}

In the practice teaching subject setting, must take into account to take part in the practice teaching class in supporting role of background knowledge. This set of practice teaching theme of "biological technology and application of industry practitioners should possess professional morality accomplishment", closely combine professional ethics accomplishment and professional class, the students in the process of job completion, not only to understand the concept of morality, professional ethics, and through to the "biological technology and application of" professional, industry information collection, from a technical level to grasp to understand the biological technology and application of "the connotation and extension of professional, industry. Through professional and industry professional requirements, induces the reverse should have the professional ethics of professional practitioners, enrich the students' understanding of the professional, so that the students for their professional future practitioners should have professional ethics embodies. 
Through an example of this teaching method, students' ability of autonomous explain get greatly improved, also make the students encountered a similar situation again in the future know how to learn.

\section{Acknowledgment}

Introducing examples of German vocational education teaching in higher vocational colleges and universities thought politics theory class practice teaching is a kind of education teaching method of exploration, the author hope to draw lessons from developed countries vocational education teaching means and methods to promote the teaching effect of ideological and political theory course in higher vocational college students, enhance education of ideological and political theory teaching pertinence, effectiveness and persuasion and appeal.

\section{References}

[1] JiangDaYuan. Study of contemporary mainstream German vocational education teaching thought. Beijing: Tsinghua university press, In April 2007 the first edition. 